\title{
Bp1-3 イネ澱粉合成関連䣼素間の相互作用
}

秋田県大 ·生物資源科学 1 , Univ. Potsdam ${ }^{2}$

O中村保典 ${ }^{1}$ ，小野雅美 ${ }^{2}$ ，相原里美1，内海稚佳子1，M. Steup ${ }^{2}$ ，藤田直子

【目的】澱粉は基本的に直鎖伸長反応、分岐形成反応、クラスタ一構造のトリミング反応の組み合わせによって合成される。本研究では、 精製酵素を用いた in vitro 実験により、直鎖伸長反応を触媒するプラスチド型ホスホリラ一ゼ Phol またはスターチシンターゼ SS と分岐 形成反応を触媒する枝作り酵素 BE との相互作用の性質を解析し、両者の相互作用の澱粉合成過程における意義を考察する。今回は Phol-BE 相互作用を中心に発表する。

【方法】 Phol は乳熟期のイネ種子から、イネSS と BE アイソザイムはリコンビナント酵素から精製し、反応に用いた。

【結果】1.Phol とSS はグルカンプライマーが存在しない条件では、単独では伸長反応 (グルカン合成) 活性を示さないが、BE が共 存すると、多量のデキストリンまたはグルカンが合成される。2．グルカンプライマーを添加しない条件下での Phol-BEI 相互作用にお いて、Phol 機能はBEIによって活性化され、BEI 機能はPhol によって活性化される。SSI-BEI 反応においても同様である。3.Pho1-BEI およびSSI-BEI 相互作用は分岐デキストリンまたは分岐グルカンを介する。4 . 反応液中にイソアミラ一ゼを添加しても、Pho-BEI のグ ルカン合成能そのものには直接影響しない。以上の結果から、Phol-BEI 相互作用は両酵素の個別の性質から想定される以上の相乗的な 効果を示しており、本相互作用は澱粉合成初期過程において重要な役割を果しているものと推測される。

\section{Bp1-4}

シアノバクテリア由来GH13 およびGH57 Branching enzyme の機能解析

秋田県立大学 - 生物資源科学部

○鈴木龍一郎, 藤田直子，鈴木英治

【目的】 Branching enzyme (BE; EC 2.4.1.8)は、 $\alpha$ グルカンを基質として $\alpha-1,4$ 結合を切断し、6 位に転移して分岐を作る分子内糖転移 反応を触媒する。BE は、糖加水分解酵素ファミリーGH13 および GH57 に属している。シアノバクテリアは普遍的に GH13BE および GH57BE 両方を持つ点でユニ一クである。Synechococcus elongatus PCC7942 変異株を用いた予備的解析から、両者の BE は貯蔵 $\alpha$ グルカンの合成 に関与することが示唆された。そこで本研究では、S. elongatus PCC7942 株由来GH13BE およびGH57BE の遺伝子をクロ一ニングし、それ ぞれのリコンビナント酵素の機能を比較したので報告する。

【方法】S. elongatus PCC7942 株由来の GH13BE およびGH57BE をクローニングし、これらのリコンビナント酵素を大腸菌内で発現させ、 Ni アフィニティークロマトグラフィーによって精製した。アミロースを基質として酵素反応を行い、ヨウ素染色、Native-PAGE 活性染色、 キャピラリ一電気泳動法による鎖長分布解析で醭素活性を検出した。

【結果】GH13BE を大腸菌内で発現させたところ、可溶性画分に十分な量の発現力確認された。それに対して GH57BE は可溶性画分にほと んど発現しておらず、大部分が封入体となった。そこで GH57BE を分子シャペロンと共発現させたところ、封入体形成か軽減し可溶性画分 への発現が促進された。平均分子量の異なる市販のアミロース 3 種類を基質として GH13BE および GH57BE の醭素反応を行ったところ、両 者の間で基質特異性に差異が見られた。

\section{Bp1-5 イネ顆粒結合型デンプン合成醭素のX 線結晶構造解析}

\section{(独) 農業生物資源研究所}

O門間充, 藤本瑞

【目的】デンプンは植物によって合成され、植物自身のみならず微生物より人類にいたる生物の重要なエネルギ一源である。さらに、食 品製造、製紙工業やバイオエタノール生産等の原料としても利用されている。数種類あるとされるデンプン合成酵素について、これまで に生化学的·分子生物学的研究を含めた多くの研究が行われているが、三次元立体構造は未涪明らにこれていない。我々はデンプン生 合成の分子機構解明研究の一環として、イネ顆粒結合型デンプン合成醭素活性ドメイン (GBSSI-CD) のX 線結晶構造解析を行った。

【方法】イネGBSSI-CD の配列をPCRにより増幅し、プラスミドに組み込み大腸菌で発現した。シッティングドロップ蒸気拡散法を用いて 結晶化スクリーニングを行い、高エネルギ一加速器研究機構放射光施設においてX 線回折データを収集した。バクテリアのグリコーゲン 合成酵素 (GS) の構造をもとにした分子置換法を利用して、構造解析を行つた。

【結果】GBSSI-CD は可溶性で発現し、常法に従し精製した。硫酸リチウムを沈殿剂とする結晶化条件下で、空間群 $P_{432}$ に属する塊状結晶 が得られた。分解能 2.7Aで構造決定した結果、本酵素はN 末、C 末に2つのRossmann フォールドを持つ糖転移酵素ファミリー5 (GT-5) に属する酵素の特徵的立体構造を有していた。活性部位にADP の結合した構造も決定し、その結果本酵素の活性部位は微生物 GS と同様に N, C 両ドメイン間に存在することが明らかとなった。

\section{Bp1-6*}

高温ストレスにより発生した白未熟米粒の定量的プロテオーム解析

新潟大院 $\cdot$ 自然科学 ${ }^{1}$, 新潟大農 - 応生化 ${ }^{2}$, 新潟農総研 $\cdot$ 作物研 ${ }^{3}$

○丸山達也 ${ }^{1}$ ，佐々木麻衣子 ${ }^{2}$, 白矢武士 ${ }^{3}$, 金古堅太郎 ${ }^{2}$, 三ツ井敏明 1.2

【目的】近年、地球温暖化に伴いイネ登熟期の異常高温による白未熟米粒の多発か㵍題となっている。これは機能タンパク質発現の異常 や光合成産物の転流効率低下など様々な要因が複雑に重なり生じることが想定されるが、詳細は明らかではない。本研究の目的は、高温 登熟障害米の発生機構を明らかにすることである。

【方法】高温環境下で発生率の高い心白米、背白米、基白米の乳白部位と、乳白が形成されていない種子の正常部位からそれぞれタンパ ク質を抽出し、iTRAQ 法による定量的プロテオーム解析を行った。

【結果】正常部位と比べ乳白部位においてはデンプン代謝関係や転写・翻訳関係、活性酸素種消去系酵素・ヒートショックプロテインと いったストレス応答関係のタンパク質の発現が増加する傾向が見られた。特に、デンプン代謝については、分解に関係する酵素の発現が

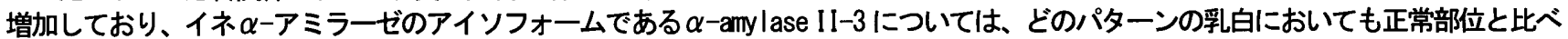
発現が増加していることが示された。それに対し、Branching enzymeやStarch synthase といったデンプン合成に関係する酵素の発現量 に大きな違いは見られなかった。以上の結果から、高温ストレスによる乳白形成には、デンプン合成系よりもむしろデンプン分解系の異 常が大きく関与していることが示唆された。 